\title{
Evaluation by microarray of the potential safety of Sarracenia purpurea L. (Sarraceniaceae) a traditional medicine used by the Cree of Eeyou Istchee
}

Carolina Cieniak ${ }^{1}$, Charlotte McDonald ${ }^{1}$, John $\mathrm{Nash}^{2}$, Asim Muhammad ${ }^{3}$, Alaa Badawi², Pierre S. Haddad ${ }^{4}$, Alain Cuerrier $^{5}$, Steffany A.L. Bennett ${ }^{6}$, Brian C. Foster ${ }^{7}$, John T. Arnason ${ }^{1}$.

${ }^{1}$ Biology Department, University of Ottawa, Ottawa, ON, Canada. ${ }^{2}$ Office of Biotechnology, Genomics and Population Health, Public Health Agency of Canada, Toronto, ON, Canada. ${ }^{3}$ Department of Chemistry, University of Ottawa, Ottawa, ON, Canada. ${ }^{4}$ Department of Pharmacology, Université de Montréal, Montréal, QC, Canada. ${ }^{5}$ Jardin botanique de Montréal, Institut de recherche en biologie végétale, Université de Montréal, Montréal, QC, Canada. ${ }^{6}$ Neural Regeneration Laboratory, Ottawa Institute of Systems Biology, Department of Biochemistry Microbiology and Immunology, University of Ottawa, Ottawa, ON, Canada. ${ }^{7}$ Department of Cellular and Molecular Medicine, University of Ottawa, Ottawa, ON, Canada.

Received, July 9, 2015; Revised, August 27, 2015; Accepted, September 14, 2015; Published, October 13, 2015.

ABSTRACT - Purpose: The purpose of this study was to assess safety of the traditional antidiabetic extracts of either S. purpurea or its lead active principle, morroniside at the transcriptional level. The overarching objective was to profile and validate transcriptional changes in the cytochrome P450 family of genes, in response to treatment with $S$. purpurea ethanolic extract or its lead active, morroniside. Methods: Transcriptional activity was profiled using a $19 \mathrm{~K}$ human cDNA microarray in C2BBe1 cells, clone of Caco-2 intestinal cells, which are a model of first-pass metabolism $(1,2)$. Cells were treated with $S$. purpurea extract for 4 and 24 hrs, as well as the pure compound morroniside for $4 \mathrm{hrs}$, to determine their effects. Results: No evidence of cytochrome P450 transcriptome regulation or of transcriptional activation of other diabetes relevant mRNA was detected after rigorous quantitative-PCR validation of microarray results. Conclusion: Our data do not support a transcriptional mechanism of action for either S. purpurea extract or its lead active, morroniside.

This article is open to POST-PUBLICATION REVIEW. Registered readers (see "For Readers") may comment by clicking on ABSTRACT on the issue's contents page.

\section{INTRODUCTION}

The Cree of Eeyou Istchee (CEI) of James Bay in Northern Quebec are experiencing a rate of Type 2 diabetes (T2D) which is three to five times higher than that of the general Canadian population. More than one Cree adult in five has been diagnosed with diabetes (3). This rate is high due to both environmental and genetic factors but is further compounded by low compliance with conventional medicines $(4,5)$. The transition from a traditional diet and life on the land to a modern diet and sedentary lifestyle is a major contributing cause. To address the need for alternate culturally acceptable options, the Cree communities of Eastern James Bay and their Cree Health Board initiated a research project to examine the safety and efficacy of culturally relevant medicines and plant products in collaboration with the CIHR Team in Aboriginal Antidiabetic Medicines. Ethnobotanical surveys were performed between 2003 and 2011 identifying traditional medicines used to treat symptoms of T2D $(6,7)$. One of the top plants used was the pitcher plant, Sarracenia purpurea, where either whole plants or leaves were used for treatment.

Sarracenia purpurea L. (Sarraceniaceae), also known as Ayigadash in Cree, is a carnivorous plant found throughout North America that grows near nitrogen-poor environments such as bogs and peat lands (8). Its leaves form pitchers that collect rainwater and, with the help of variety of bacteria, break down and absorb the necessary nutrients from insects trapped in the pitchers (9). Initial screening of $S$. purpurea by our team discovered its potent insulinomimetic activity on glucose uptake in muscle cells, higher than that of the most widely used antidiabetic therapy, metformin (10).

Correspondence Author: Brian C. Foster, Ph.D., Faculty of Medicine, Department of Cellular and Molecular Medicine, University of Ottawa, Ottawa, ON, Canada. Email: bfoste2@uottawa.ca. 
Furthermore, it was shown to be neuroprotective in states of both high and low glucose toxicity, when tested on PC12 cells $(10,11)$. Recently, it has been shown that $S$. purpurea mediates its activity through a metformin-like mechanism, activating the adenosine-monophosphate-activated protein kinase (AMPK) and disrupting mitochondrial energy transduction (12). The pleiotropic AMPK pathway regulates metabolism, autophagy, and cell growth, making it a very potent target for metabolic disease (13-17). Together, these data further supported $S$. purpurea's identification as a traditionally relevant antidiabetic therapy.

$S$. purpurea contains numerous active compounds, many of which have been isolated through bioassay-guided fractionation $(11,18)$. One of the active principles is morroniside (MNS), an iridoid glycoside, responsible for protection of cells from cytotoxicity in the presence of glucose toxicity (11). Morroniside has also been isolated by other groups from Cornus officinalis, a traditional Chinese medicine, and shown to possess potent antioxidant, antiapoptotic, and antidiabetic activities both in vitro and in vivo (19-21).

The safety of natural health products was of upmost importance to the Cree Elders and Healers. Traditional medicines can potentially contribute to adverse reactions as patients not only take one or more of these medicines, but due to an increase in prevalence of other diseases, such as coronary artery disease, are more likely to be treated by other therapies as well (4). These interactions are often manifested by inhibition or upregulation of the cytochrome $\mathrm{P} 450$ family (CYP) of metabolic enzymes responsible for breakdown of xenobiotics (22). Any dysregulation to the CYPs has the potential to affect other pathways and networks and may cause adverse effects either by increasing the load of another drug and hence increasing toxicity or not providing the drug in high enough concentration as to render it ineffective (22-27). Work done by our group on a limited number of CYP enzymes has suggested that the CEI traditional medicines have the potential for such interactions in in vitro enzyme assays $(28,29)$. However, some plants work by disrupting $C Y P$ transcription, which has not been evaluated for $S$. purpurea or any other Cree medicinal plant.

As plants generally possess a wide variety of phytochemicals, they may affect more than one pathway or network that may not be adequately assessed by cell free in vitro assays. The objective of this work was then to determine if $S$. purpurea extract, or a known active, morroniside (MNS) could affect transcriptional changes in a wide range of pathway and network transcripts associated with drug disposition and other metabolic functions using a $19 \mathrm{~K}$ human cDNA microarray in Caco-2 intestinal cells $(1,2)$.

\section{MATERIALS AND METHODS}

\section{Materials and sample preparation}

$S$. purpurea leaves were harvested from the Eastern James Region, Quebec, Canada, following directives by the healers and elders of the community. Dr. A. Cuerrier confirmed the botanical identity of the plant and a voucher specimen \# 2003-05 was deposited at the Marie-Victorin herbarium at the Montreal Botanical Garden, Montreal, Quebec, Canada (6, 7). Leaves were subsequently extracted with ethanol, lyophilized, and analysed for phytochemical markers as previously described $(18,30)$. The crude extract was dissolved in dimethyl sulfoxide (DMSO) (Sigma-Aldrich, Oakville, ON, Canada) at a concentration of $100 \mathrm{mg} / \mathrm{mL}$ and filter sterilized with RC $0.20 \mathrm{~nm}$ filters (Corning Costar Co., NY, USA) to obtain a sterile stock.

The pure compound morroniside (Figure 1) was isolated from $S$. purpurea using column chromatography and spectroscopic methods (18, 30). It was dissolved in DMSO at a concentration of $10 \mathrm{mg} / \mathrm{mL}$ and filter sterilized with RC $0.20 \mathrm{~nm}$ filters to obtain a sterile stock.

\section{Cell Culture}

The C2BBe1 cell line, a clone of the Caco-2 colorectal adenocarcinoma cell line was obtained from the American Type Culture Collection (Cat\# CRL-2102, Manassas, VA, USA). The cells were cultured in Dulbecco's Modified Eagle Medium (DMEM) with 10\% Fetal Bovine Serum, 100 units $/ \mathrm{mL}$ of penicillin-streptomycin, $0.01 \mathrm{mg} / \mathrm{mL}$ lyophilized human transferrin and $4 \mathrm{mM}$ Lglutamine. All cell culture reagents were purchased from Life Technologies (Burlington, ON, Canada). Cell culture was performed under sterile conditions and cultures were grown in a humidified incubator at $37^{\circ} \mathrm{C}$ with $5 \% \mathrm{CO}_{2}$.

\section{Caco-2 plant exposure}

The cells were counted with a haemocytometer and plated at a concentration of 300000 cells/well in a 


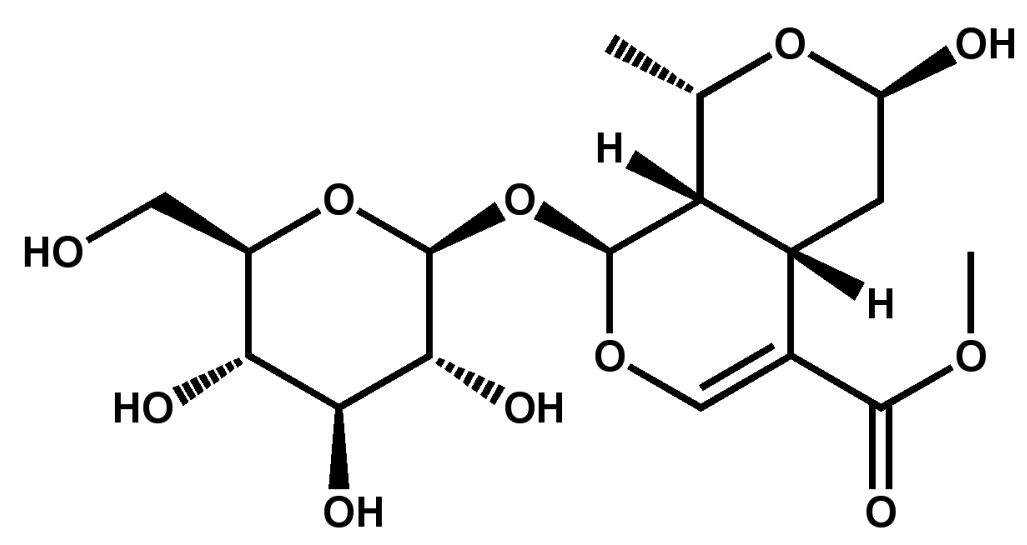

Figure 1. Structure of morroniside (MNS).

24-well plate (Corning Costar Co., NY, USA) with a final volume of $500 \mu \mathrm{L}$. The cells were allowed $24 \mathrm{hrs}$ to attach to the plate before the media was changed and the treatment was added. The experimental cells were treated with $100 \mu \mathrm{g} / \mathrm{mL}$ of S. purpurea extract in $0.1 \%$ DMSO or $8.8 \mu \mathrm{g} / \mathrm{mL}$ morroniside in $0.1 \%$ DMSO and control cells were treated with $0.1 \%$ DMSO. After 4 or $24 \mathrm{hrs}$ of incubation, the RNA was extracted. Twelve control and 12 treated samples were generated per experiment.

\section{RNA Extraction}

RNA extractions were performed according to protocol using the Qiagen RNeasy kit (Cat\# 74106). The Qiashredder (Cat\# 79654) was used to homogenize the cells and an on-column DNase treatment with the RNase-Free DNase Set (Cat\# 79254) was used to remove DNA contamination. The kit and additional components were purchased from Qiagen (Toronto, ON, Canada). The RNA was eluted into $30 \mu \mathrm{L}$ of RNase free water and immediately stored at $-80^{\circ} \mathrm{C}$.

\section{RNA Quantity and Quality}

Before experiments were performed on the sample, the quality and quantity of the RNA was measured. The quantity of RNA was measured using the NanoDrop ND-1000 UV-Vis Spectrophotometer to measure absorbance at $260 \mathrm{~nm}$ and $280 \mathrm{~nm}$. The quality of RNA was determined as per included protocol with the Agilent 2100 Bioanalyzer using the RNA 600 Nano LabChip Kit (Cat\#5065-4476, Agilent Technologies, Mississauga, ON, Canada). The 2100 Expert software analyzed the results of the run to produce an electropherogram and a gellike image for each RNA sample. All samples had an RNA Integrity Number (RIN) higher than 9.

\section{Microarray}

Human 19K cDNA microarrays were obtained from the University Health Network Microarray Centre (Array\# H19K, Toronto, ON, Canada). The 12 control samples were pooled to produce a single control pool (CTRL). The treated samples were pooled into four pools (TRT1, TRT2, TRT3, TRT4), with three samples each. These RNA pools were used for the microarray experiments as per the 3DNA Array 900 MPX protocol, the Cy3 Kit (Genisphere, Hatfield, PA, USA) and the Cy5 Kit (Genisphere, Hatfield, PA, USA) were used. Two of the treated samples were labelled with $\mathrm{Cy} 3$ and the two remaining treated samples were labelled with Cy5, with the control being labelled with the alternative tag for each slide. The slides were also treated with Cot-1 DNA (Life Technologies, Burlington, ON, Canada) in the prehybridization step to minimize background. The microarray slides were read with the Scanarray 5000XL (Packard Biochip Technologies, Erie, PA, USA) using Scanarray Express software and analyzed with Quantarray software.

\section{Microarray Analysis}

Data was converted from the format output used by the Scanarray scanner (Packard Biochip Technologies, Erie, PA, USA) to the .mev format used by the TIGR's TM4 suite of array analysis tools (http://www.tm4.org/) using an in-house Microsoft Excel script. Raw data was normalized 
using Lowess and in-slide SD normalizations (http://pfgrc.jcvi.org/index.php/bioinformatics/gink go.html), and missing values were removed. Data was imported into TM4's MeV array analysis program for further analysis. Appropriate dye-swap experiments were used to accommodate any biases, which could occur using a single dye. These results were treated as replicates within $\mathrm{MeV}$. Analyses were performed using the Significance Analysis of Microarray (SAM) algorithm (31) and a list of differentially expressed genes was generated using a false discovery rate of $1.5 \%$. Fold change values were transformed using $\log _{2}$.

\section{Reverse transcription to cDNA}

Each RNA pool (CTRL, TRT1, TRT2, TRT3, TRT4) was converted to cDNA using Superscript II RNAse H RT with buffer and DTT (Life Technologies, Burlington, ON, Canada). Briefly, a $2 \mu \mathrm{g}$ sample of RNA was combined with $1 \mu \mathrm{L}$ of pdN6 random primers (Promega Corporation, Madison, WI, USA) and NF- $\mathrm{H}_{2} \mathrm{O}$ to make a $12 \mu \mathrm{L}$ reaction. The samples were incubated at $70^{\circ} \mathrm{C}$ for $10 \mathrm{~min}$ followed by $4^{\circ} \mathrm{C}$ for $2 \mathrm{~min}$ in the Biometra PCR Thermocycler (Biometra, Goettingen, Germany). A $7 \mu \mathrm{L}$ aliquot of a mastermix consisting of $4 \mu \mathrm{L}$ of First Strand Buffer, $2 \mu \mathrm{L}$ DTT $(0.1 \mathrm{M})$ and $1 \mu \mathrm{L}$ dNTPs $(10 \mathrm{mM})$ was added to each tube, and each sample further incubated at $37^{\circ} \mathrm{C}$ for $2 \mathrm{~min}$ then cooled to $25^{\circ} \mathrm{C}$ again using the Biometra Thermocycler. A $1 \mu \mathrm{L}$ of Superscript RT was then added to the reaction and the tubes further incubated at $25^{\circ} \mathrm{C}$ for $10 \mathrm{~min}, 42^{\circ} \mathrm{C}$ for $60 \mathrm{~min}$, $50^{\circ} \mathrm{C}$ for $30 \mathrm{~min}$ and $4^{\circ} \mathrm{C}$ for infinity. A negative RT control (nRT) was also ran at the same time consisting of $2 \mu \mathrm{g}$ of each RNA sample and a $1 \mu \mathrm{L}$ of $\mathrm{NF}-\mathrm{H}_{2} \mathrm{O}$ instead of the RT enzyme, as well as a no template control consisting of $\mathrm{NF}-\mathrm{H}_{2} \mathrm{O}$ instead of RNA. Furthermore, a Reference cDNA was also created using $2 \mu \mathrm{g}$ of Stratagene QPCR Reference Total RNA (Cedarlane, Burlington, ON, Canada). The cDNA samples were stored at $-80^{\circ} \mathrm{C}$.

\section{Efficacy of genomic DNA removal}

The cDNA was verified for genomic contamination using an in lab GAPDH (glyceraldehyde-3phosphate dehydrogenase) protocol. Briefly, a $1 \mu \mathrm{L}$ sample of each RT reaction including controls was combined with $24 \mu \mathrm{L}$ of a mastermix containing 18 $\mu \mathrm{L}$ of NF-H2O, $2.5 \mu \mathrm{L}$ of 10X Titanium Buffer (Clontech, Mountain View, CA, USA), $2 \mu \mathrm{L}$ dNTPs $(10 \mathrm{mM}), 0.5 \mu \mathrm{L}$ each of forward and reverse
GAPDH primers, and $0.5 \mu \mathrm{L}$ of Titanium Taq DNA Polymerase (Clontech, Mountain View, CA, USA). The sequence of the forward primer was 5'-TGG TGC TGA GTA TGT CGT GGA GT-3' and of the reverse was 5'-AGT CCT CTG AGT GGC AGT GAT GG-3'. A no template control consisting of NF- $\mathrm{H}_{2} \mathrm{O}$ instead of RT reaction product was also run. The samples were run on a Bio-Rad PCR thermocycler (Bio-Rad, Mississauga, ON, Canada) using the following cycling conditions: $94^{\circ} \mathrm{C}$ for 5 min, followed by 35 cycles of $94^{\circ} \mathrm{C}$ for $25 \mathrm{~s}, 59^{\circ} \mathrm{C}$ for $50 \mathrm{~s}$ and $72^{\circ} \mathrm{C}$ for $105 \mathrm{~s}$, then 1 cycle of $72^{\circ} \mathrm{C}$ for $7 \mathrm{~min}$ and $4^{\circ} \mathrm{C}$ for infinity. The products of the reactions were visualized with ethidium bromide on a $1 \%$ agarose gel (results not shown).

\section{Real-time quantitative PCR (qPCR)}

The qPCR was performed using Applied Biosystems' Taqman Gene Expression Assays (Life Technologies, Burlington, ON, Canada) on a Stratagene Mx3005P qPCR machine (Agilent Technologies, Mississauga, ON, Canada). The assays used were the following: mTOR (FRAP1), mammalian target of rapamycin - Hs00234508_m1, $B E C N 1$, beclin 1 - Hs00186838_m1, TAP1, transporter 1, ATP-binding cassette, sub-family B Hs00388675_m1, ABCA2, ATP-binding cassette, sub-family A (ABC1), member 2 Hs00242232_m1, PRKCD, protein kinase C delta Hs01090047_m1, CYP2D6, cytochrome P450 2D6 - Hs02576168_g1 all labelled with a FAM tag and RPLP0, large ribosomal protein P0 - 4326314E used as a housekeeping gene labelled with VIC. The reaction was performed according to manufacturer's instructions. The cycle threshold $(\mathrm{Ct})$ value was measured at the end of each cycle based on fluorescence using the FAM/SYBR and VIC/HEX filters.

Initially, the linear range of each Taqman assay was determined using the Reference cDNA using a two-fold standard curve starting at 1/12.5 going to $1 / 200$, representing 40 to $2.5 \mathrm{ng}$ of RNA, with each dilution ran in duplicate. The $\mathrm{Ct}$ values were graphed against $\log [\mathrm{RNA}]$ in GraphPad Prism 6.0 (GraphPad, La Jolla, CA, USA) and an $\mathrm{R}^{2}$ value obtained based on the best three or more points. It was determined that a $1 / 25$ dilution of the samples would be ideal to show an increase or a decrease in fold change. Then for each gene of interest a standard curve consisting of the Reference cDNA was ran with the actual cDNA samples (CTRL, TRT1, TRT2, TRT3, TRT4) diluted $1 / 25$ in 
triplicate. The nRT of each pool as well as no template controls were also run. For each gene of interest for each pool, the $\log [\mathrm{RNA}]$ concentration was determined and normalized to the respective $\log [$ RNA] for the housekeeping RPLP0 gene. The values were converted to [RNA] in ng and a fold change determined for each TRT pool normalized to the CTRL pool.

\section{Three-fold qPCR changes}

The protocol for qPCR was the same as described above except the samples of interest were a $1 / 25$ sample dilution and a $1 / 75$ dilution of the CTRL pool run in triplicate for $m T O R$ and a $1 / 25$ sample dilution and a $1 / 8.3$ sample dilution run in triplicate for $B E C N 1$. The results were converted to [RNA] as described above and graphed using GraphPad Prism 6.0 .

\section{RESULTS}

Following 24-hr treatment with $100 \mu \mathrm{g} / \mathrm{mL}$ of $S$. purpurea and out of 19200 possible cDNAs at a false discovery rate stringency of $1.5 \%$, a total of 8 transcripts were found to be significantly upregulated and 54 significantly downregulated, of which 12 transcripts could not be identified (Figure 2). A similar number of altered genes was seen following a 4-hr $100 \mu \mathrm{g} / \mathrm{mL} \mathrm{S}$. purpurea exposure (Figure 3), where a total number of 62 transcripts were deregulated, however the distribution pattern differed with 32 upregulated and 30 downregulated, where 13 could not be identified. MNS after 4-hr exposure, produced the greatest number of observable changes: 137 transcripts were upregulated and 25 were downregulated, while 40 could not be identified (Figure 4). The pattern observed with the four separate arrays for each experiment was similar for each transcript, hence displaying good reproducibility.

Further pathway analysis was performed using Ingenuity software. The number of significantly altered transcripts shared between the different exposures/treatments was minimal (Figure 5). Only one transcript was altered in all three experiments, RSBN1L (round spermatid basic protein-1 like) (Table 1), and the direction of the change was variable over time showing a downregulation within the 4-hr exposure for both extract and MNS, and an upregulation following 24-hr exposure. This was consistent for the other comparisons of the 24-hr experiment with either extract or MNS at $4 \mathrm{hrs}$, where the direction of the change was always the inverse. The limited number of overlaps was surprising where only two transcripts were shared between the 4-hr and the 24-hr incubation with extract and 11 transcript changes between the 4-hr MNS and 24-hr extract. A comparison between extract and MNS at 4-hr yielded six transcripts that were altered in the same direction.

To determine whether the overall observed changes belonged to any particular cellular process, all three array experiments were examined. However, the focus of the analysis became on the 24-hr exposure, as all transcript changes were greater than two-fold as opposed to the 4-hr experiments, where only two transcripts for $S$. purpurea (including one unidentified) and five for morroniside (including two unidentified) were modified greater than two-fold. Further pathway analysis identified key transcripts in mTOR signalling where $m$ TOR (FRAPl) was significantly downregulated by a 2.6-fold change following 24-hr exposure and beclin-1 (BECNI) was significantly upregulated by a 3.1 fold change. These transcript changes were verified through the use of quantitative real-time PCR (Table 2). No change was observed for both $m T O R$ and BECN1 with qPCR. $A B C A 2, P R K C D, T A P 1$ but not CYP2D6 were significantly altered on the microarray, with changes greater than two-fold (Table 2). None of the transcripts were altered in the qPCR experiment. To confirm methodological sensitivity a corresponding increase or decrease was noted when $1 / 3$ or $3 X$ cDNA was used (Figure 6). With decreased cDNA a three-fold decrease in the mTOR gene expression was detected, and when three times the amount of starting material was used with BECN1 Taqman assay, a corresponding three-fold increase was noted. Taken together, these data indicate that both $S$. purpurea and MNS have little, to no, transcriptional effects in Caco-2 cells.

\section{DISCUSSION}

While traditional Cree medicinal plants have been shown to have potent antidiabetic activity $(10,32-$ 35 ) their potential safety has only been evaluated in the context of potential drug interactions mediated by inhibitory effects on a limited number of CYP enzymes using an in vitro assay (28, 29). 


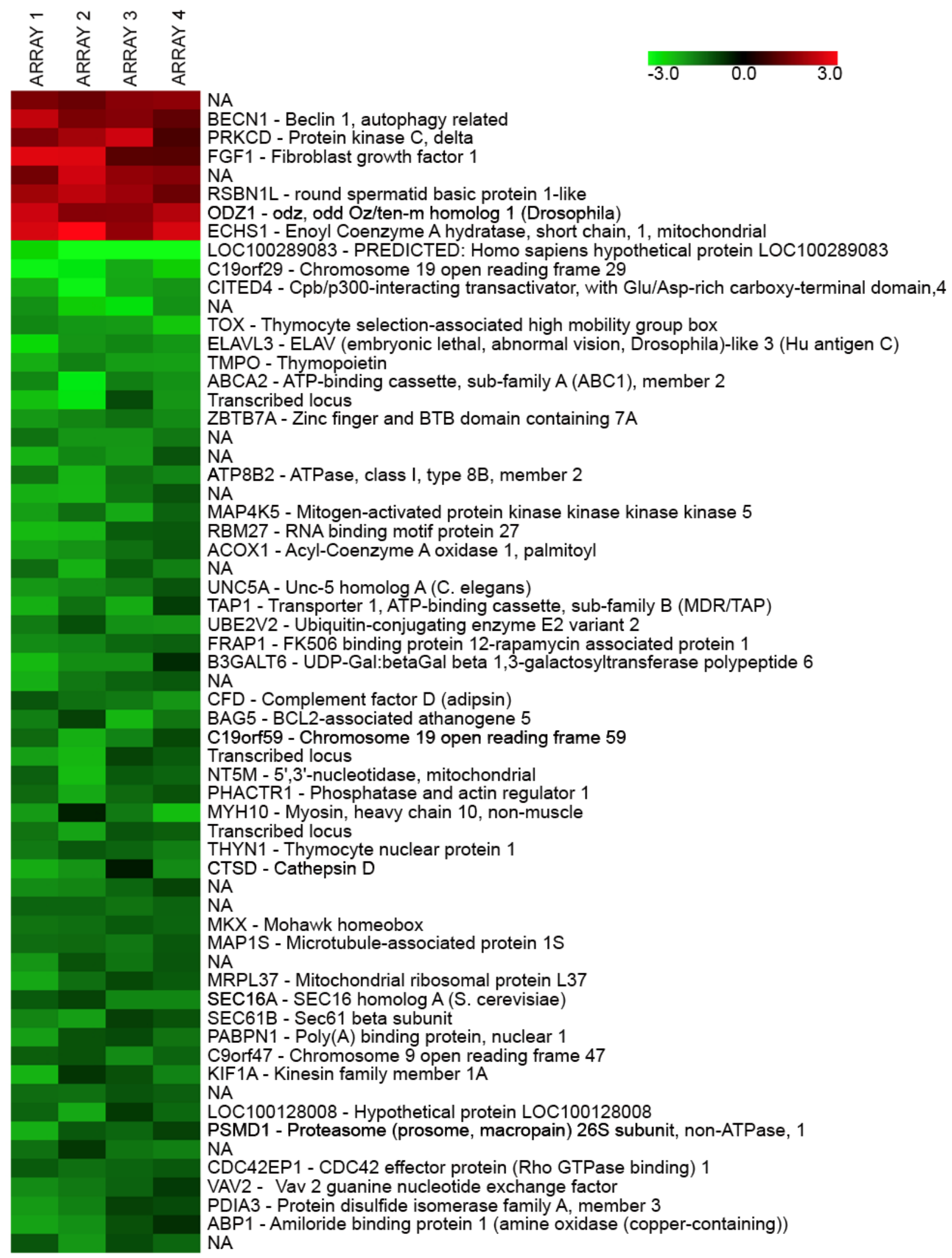

Figure 2. Upregulated and downregulated genes following treatment with $100 \mu \mathrm{g} / \mathrm{mL}$ Sarracenia purpurea for 24 hours compared to $0.1 \%$ DMSO control. Four discrete biological replicates are presented in these results. Each replicate is a combination of three separate wells of cells. 


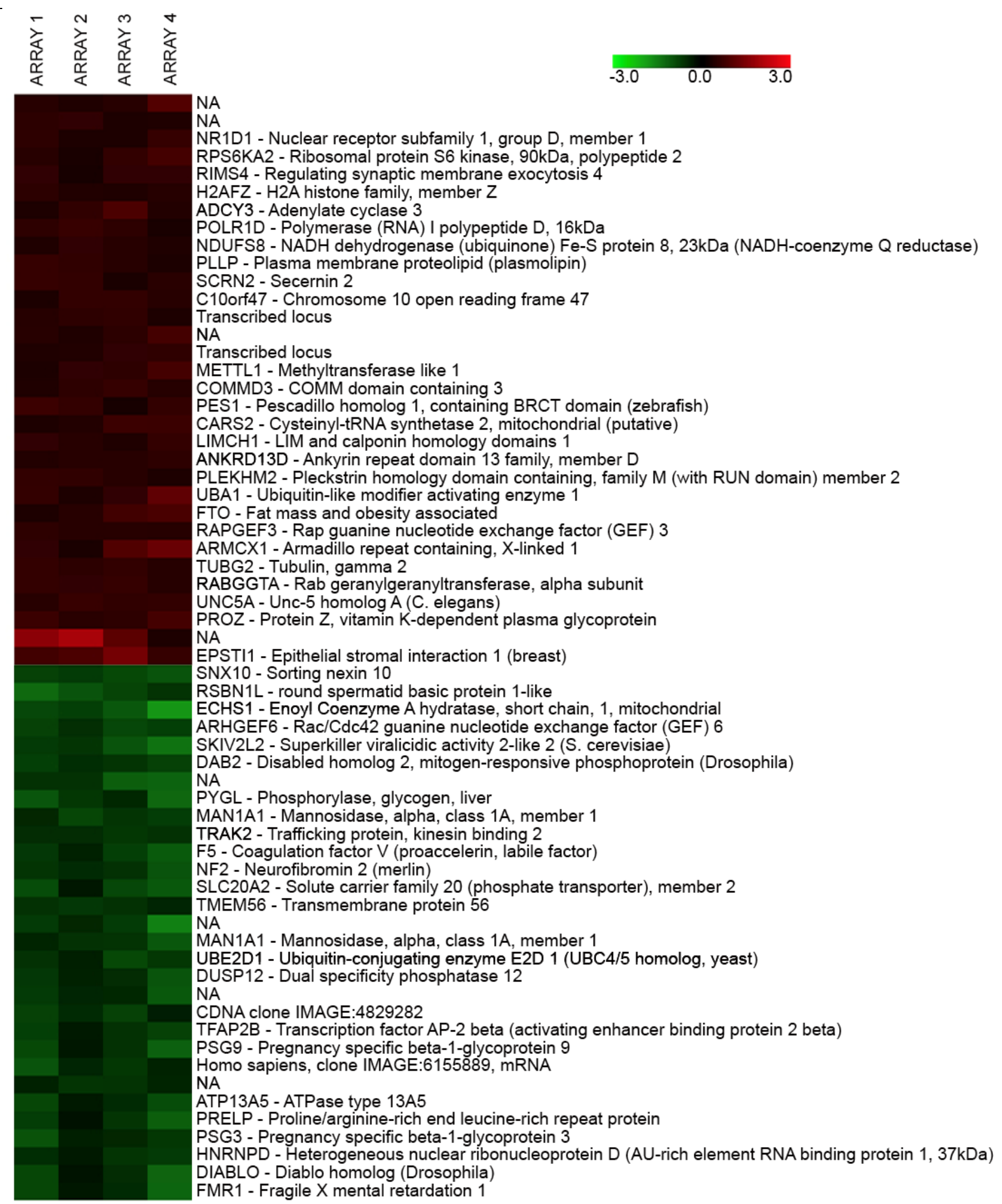

Figure 3. Upregulated and downregulated genes following treatment with $100 \mu \mathrm{g} / \mathrm{mL}$ Sarracenia purpurea for 4 hours compared to $0.1 \%$ DMSO control. Four discrete biological replicates are presented in these results. Each replicate is a combination of three separate wells of cells. 


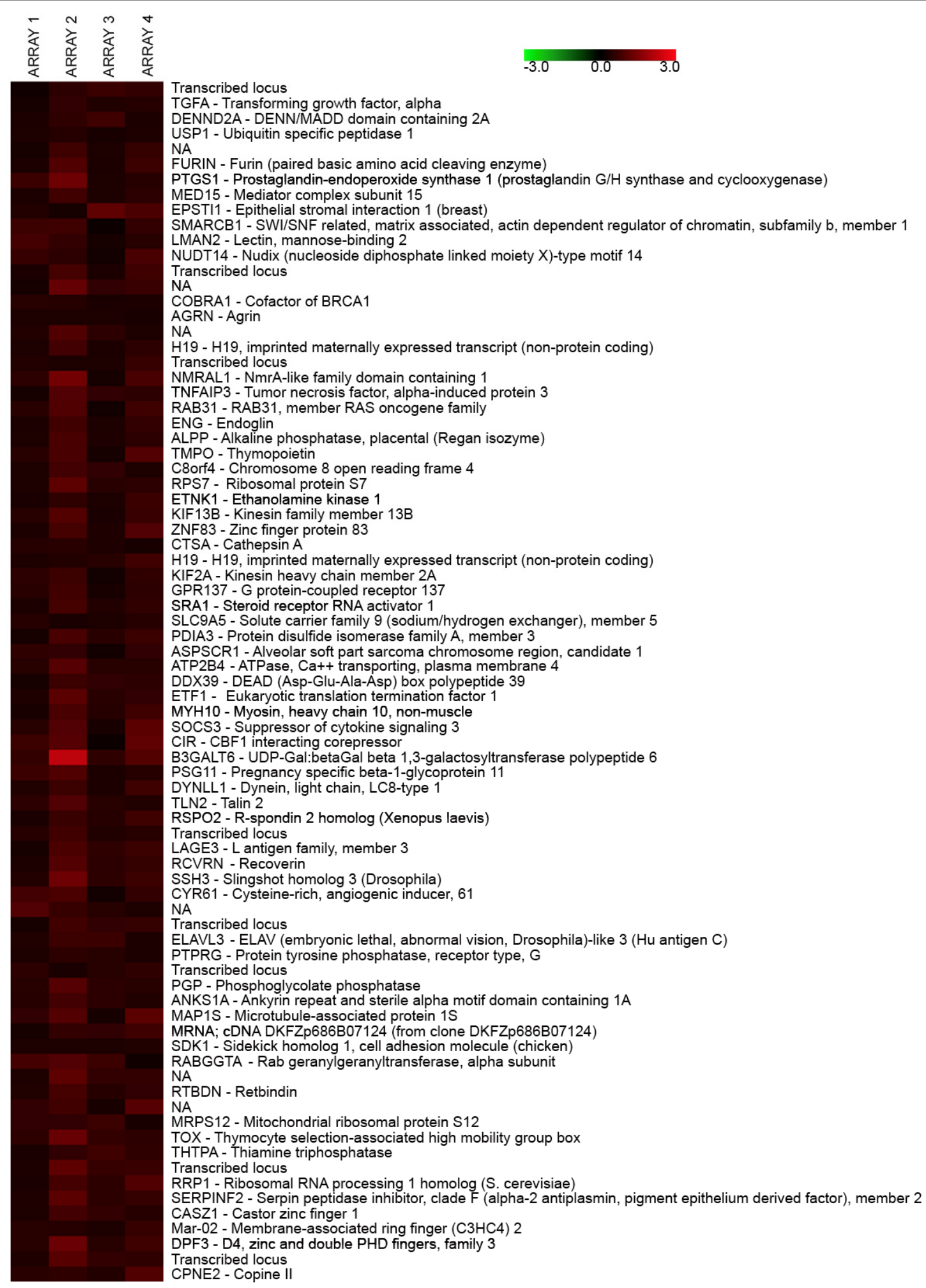

\section{Figure 4.}


Figure 4 Continued.....

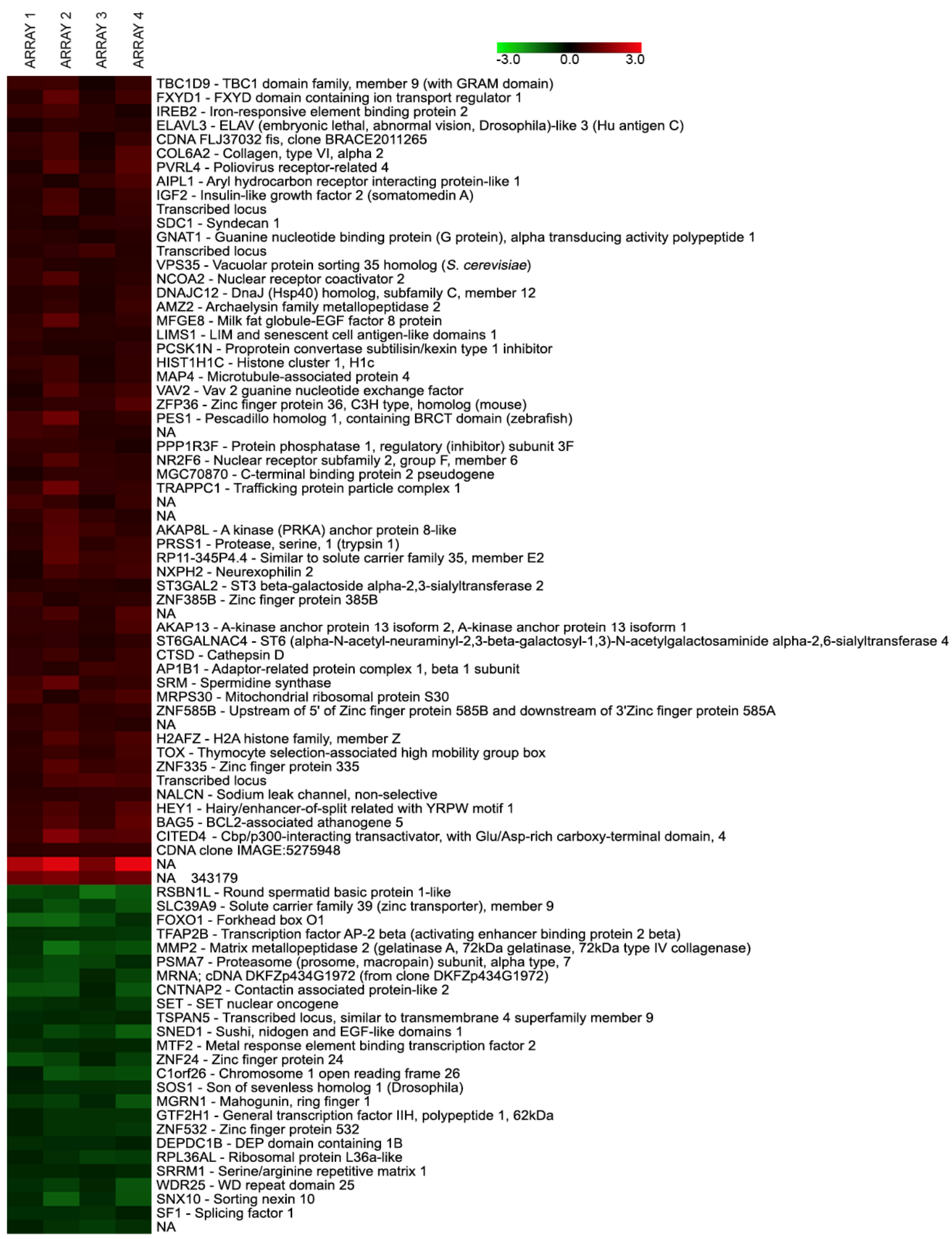

Figure 4. Upregulated and downregulated genes following treatment with $8.8 \mu \mathrm{g} / \mathrm{mL}$ morroniside for 4 hours compared to $0.1 \%$ DMSO control. Four discrete biological replicates are presented in these results. Each replicate is a combination of three separate wells of cells. 


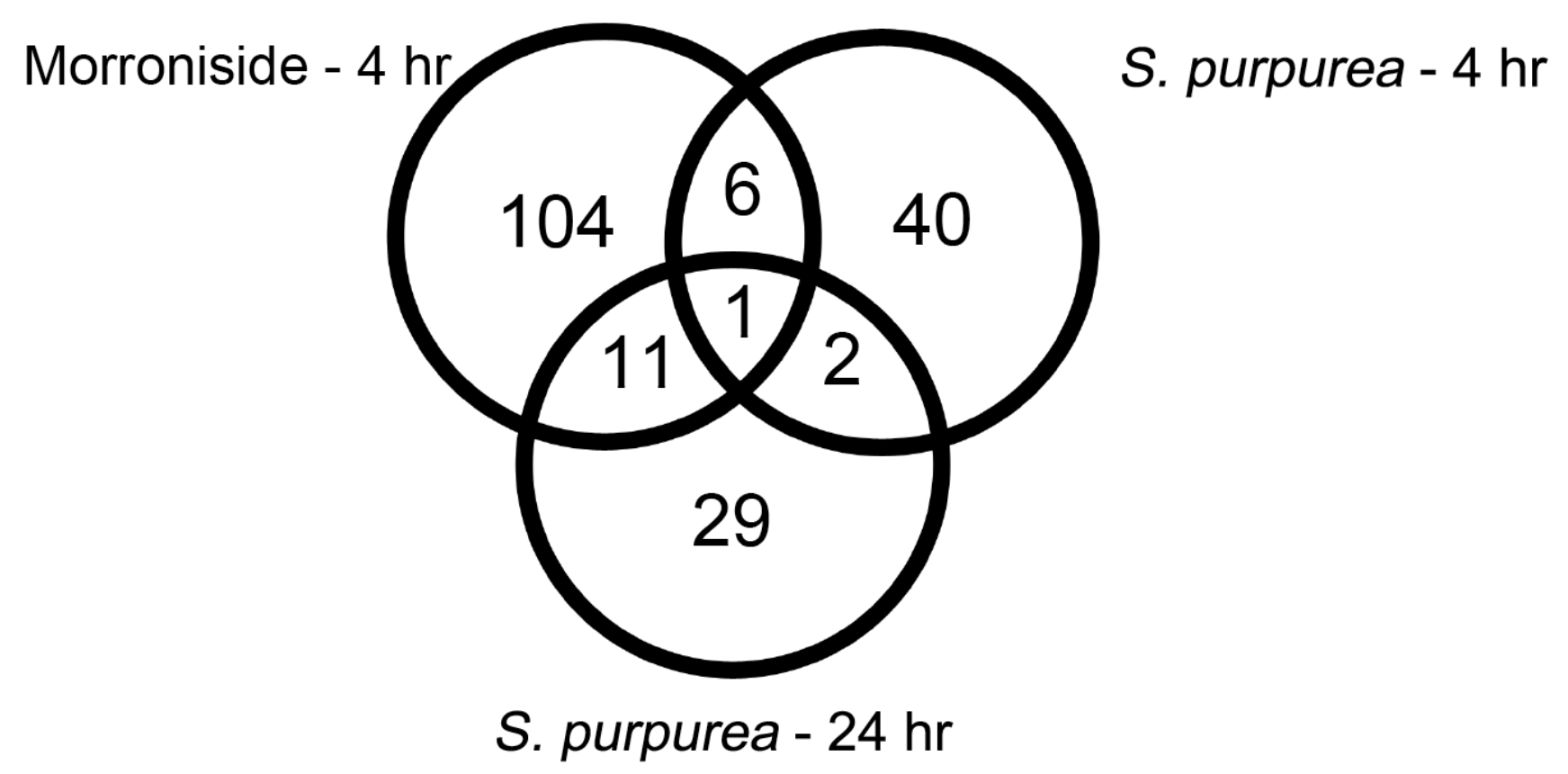

Figure 5. Overlap of shared genes that are deregulated between the three different experimental conditions with either morroniside or Sarracenia purpurea.

Table 1. List of altered genes that are represented in comparisons between the three different experiments with Sarracenia purpurea and morroniside (MNS). Bold represents genes that are consistently upregulated across specified conditions, Bold represents genes that are consistently downregulated across specified conditions, Unbolded represents no consensus. Analysis performed using Ingenuity software.

\begin{tabular}{llll}
\hline ALL & $\begin{array}{l}\text { S. purpurea } \\
\text { 4-hr and 24-hr }\end{array}$ & $\begin{array}{l}\text { S. purpurea 4-hr } \\
\text { and 1 4-hr }\end{array}$ & $\begin{array}{l}\text { S. purpurea 24-hr } \\
\text { and 1 4-hr }\end{array}$ \\
\hline RSBN1L & EPSTI1 & B3GALT6 \\
UNC5A & H2AFZ & BAG5 \\
& PES1 & CITED4 \\
& $\mathbf{R A B G G T A}$ & CTSD \\
& $\underline{\mathbf{S N X 1 0}}$ & ELAVL3 \\
& $\underline{\mathbf{T F A P B}}$ & MAP1S \\
& & MYH10 \\
& & PDIA3 \\
& & TMPO \\
& & TOX \\
& & VAV2 \\
\hline
\end{tabular}


A

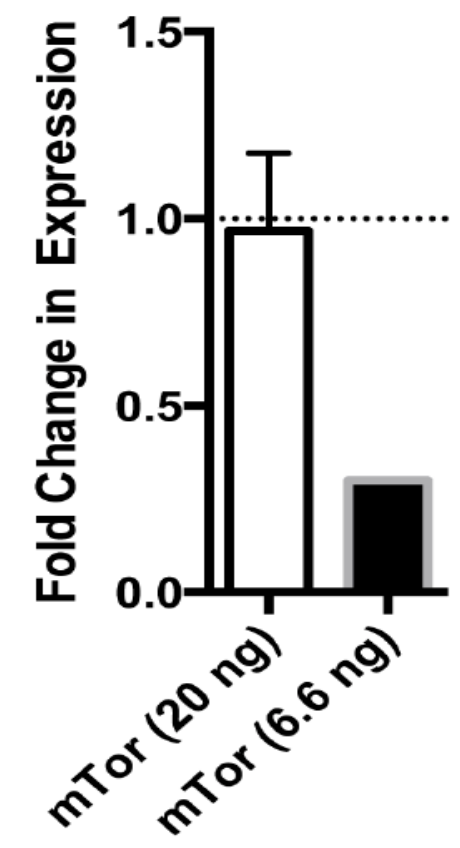

B

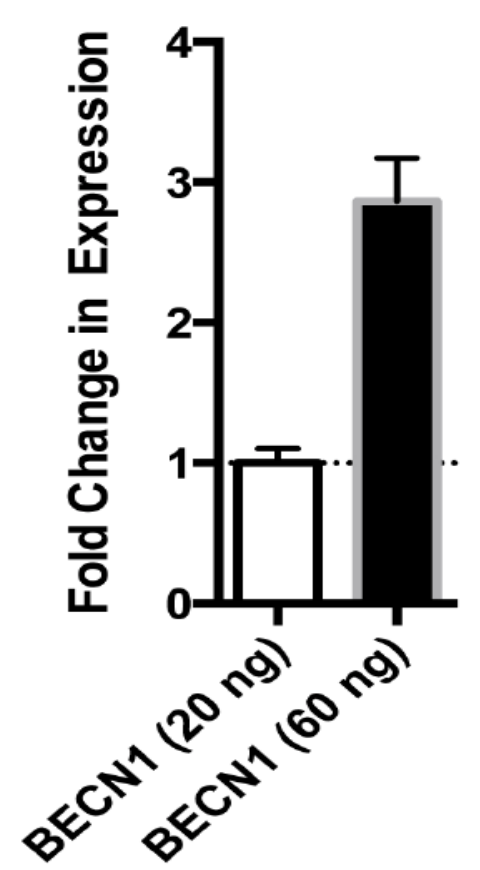

Figure 6. Three-fold change in expression as determined by qPCR. (A) A 1/25 dilution and a 1/75 dilution of CTRL pool from the 24-hour Sarracenia purpurea exposure experiment were run in a qPCR reaction using the $m T O R$ gene expression assay. (B) A 1/25 dilution and a 1/8.3 dilution of the CTRL pool from the 24-hour $S$. purpurea exposure experiment were run in a qPCR reaction using the $B E C N 1$ gene expression assay. Each dilution was run in triplicate. Mean + SEM are presented. 
Table 2. List of genes verified by qPCR using Taqman Gene Expression Assays for the 24-hour exposure of C2Bbe1 cells to $100 \mu \mathrm{g} / \mathrm{mL}$ Sarracenia purpurea.

\begin{tabular}{llll}
\hline Gene & RefSeq ID & Microarray fold change & qPCR fold change \\
\hline ABCA2 & NM_001606 & -3.7 & n.c. $^{\text {a }}$ \\
BECN1 & NM_003766 & 3.1 & n.c. \\
CYP2D6 & NM_000106 & n.c. & n.c. \\
FRAP1 & NM_004958 & -2.6 & n.c. \\
PRKCD & NM_006254 & 3.2 & n.c. \\
TAP1 & NM_000593 & -2.9 & n.c. \\
\hline${ }^{a}$ n.c. no change & & &
\end{tabular}

${ }^{a}$ n.c. no change

This present study was the first examining the effect of an important traditional medicine used by the Cree, S. purpurea, and one of its components, morroniside, on transcriptional regulation of a wide range of genes associated with drug disposition and other functions through the use of microarray technology. By using an array with a wide variety of expressed sequence tags, an untargeted approach was used to capture information. We report here that both $S$. purpurea and MNS have little to no biologically relevant effects on transcriptional activity in the genes represented in this microarray, particularly with respect to genes involved in metabolism and transport (36). A further examination of the shared genes altered by extract and MNS suggested changes in cellular development and cell assembly and organization, thus proposing an overall effect on the cell that may not be representative of the action of the plant. None of the changes belonged to the CYP family of metabolic proteins, nor to other metabolic enzymes such as GST (glutathione-S-transferase) or QR (quinone reductase), nor to any major drug transporters such as the $\mathrm{ABC}$ transporters involved in xenobiotic metabolism. This was demonstrated at a concentration higher or equal to that used by others when examining plant extracts (37-39).

This was somewhat surprising as many plants have evolved secondary metabolites in order to be resistant against microbes and insects (40) and often possess compounds that inhibit CYP450 in order to potentiate their defences. Although mostly described on a protein level (41-44), these changes may also occur on a transcript level $(37,45-48)$. Furthermore, other reports have demonstrated changes to genes important for xenobiotic disposition such as $\mathrm{ABC}$ transporters and Phase II metabolizing enzymes in response to plant extracts, including but not limited to GSTs and QRs (48-50) all present on this array but not significantly altered. Another important family of transcripts involved in conjugation of xenobiotics, UDPglucuronosyltransferases (UDPGTs), found to be altered by others (48), unfortunately were not spotted on this array.

Ingenuity Pathway Analysis of the significantly altered transcript changes revealed that the deregulated genes did not belong to a particular pathway or network. What was evident, however, was the biphasic nature of the effect of the plant extracts, previously reported as well $(18,47)$, where the common deregulated genes between 4 and 24-hr treatments were always in the opposite direction. This has previously been reported, as plant extracts tend to produce these biphasic effects $(18,47)$. Furthermore, only a limited number of transcript changes were shared between MNS and S. purpurea at $4 \mathrm{hrs}$, thus suggesting that the action of $S$. purpurea may be mediated by MNS at that time point for those transcripts. However, no single pathway was implicated, thus suggesting multiple mechanisms of action for the plant extract. This is not surprising given the large number of bioactive compounds in S. purpurea (30) and the observation that other medicinal plants such as St John's Wort also show multiple modes of action due to presence of several bioactive constituents (51).

The 24-hr exposure was chosen over the 4-hr for further study, as transcriptional changes generally take time $(10,48,52)$ and as it is more 
representative of the extended period that the Cree take this medicine. Two key transcripts part of the mTOR signalling pathway, BECN-1 and FRAPI coding for beclin-1 and mTOR, respectively were found to be altered. This was consistent to our previously published work that $S$. purpurea can alter the AMPK pathway (12). However, these changes were not validated using qPCR, although the robust method of Taqman assays was used (53). Therefore, mRNA changes in TAP1 involved in drug resistance (54), $P R K C D$ important for insulin sensitivity (55), and $A B C A 2$ important for lipid function and metabolism (56) were selected for verification (Table 2). These three were chosen, as they were some of the most significantly deregulated genes, TAP1 and ABCA2 being downregulated and $P R K C D$ being upregulated. Again, the observed fold changes detected by microarray could not be replicated. This is not unusual as discrepancies between microarray and qPCR results have been reported in the past, both in Caco-2 experiments (49) as well as others (57). However, three-fold differences, when either three times the amount or $1 / 3$ of the starting material was used, were observed, confirming that the qPCR methodology was robust. Furthermore, the primer sets were verified to be amplifying the same transcripts as those on the cDNA microarray. Hence the difference in priming methods may be responsible for this observed difference $(58,59)$. A more confounding factor is the fact that the probe sequences for the array and the qPCR were not the same. This led to different target locations between the two methods and this has long been recognized as one of the key issues with validation $(53,59,60)$. Unfortunately, primer and probe sets for the exact location were not available.

This S. purpurea extract does not appear to affect global transcriptional changes in these cells, supporting work done by our group that the mechanism of action is on the protein level (12) and in particular tissues. Future work should further examine the mechanism of action of the plant, particularly concentrating on the mTOR signalling pathway and its possible role in combating diabetes. Moreover, from a safety standpoint, the plant extract did not alter the xenobiotic metabolizing enzymes and transporters in this array on a transcriptional level, providing some evidence to its overall potential safety; however mRNA effects in hepatocytes remain to be evaluated.

\section{ACKNOWLEDGMENTS}

Very special thanks are due to Elizabeth Coon Come, Harriet Matoush, Sandy Matoush, Charlotte Petawabano, Laurie Petawabano, Pat Petawabano, Sam Petawabano, Simeon Petawabano, and Smally Petawabano from the Cree Nation of Mistissini, and Agnes Kawapit, Eliza Kawapit, Abraham Mamianskum, and Juliet Mamianskum from Whapmagoostui First Nation as well as to Cree Elders of both nations of the Eeyou Istchee who kindly agreed to be interviewed. They made this article possible by allowing us to use, for the purposes of this research, their knowledge relating to medicinal plants, transmitted to them by their elders. Their trust has also enabled a useful exchange between Indigenous knowledge and Western science. This project was funded by a Canadian Institutes of Health Research (CIHR) Team Grant in Aboriginal Antidiabetic Medicines (CTP 79855) to AC, PH, SALB, JTA, and BCF, CIHR (MOP 62826) to SALB and JTA, CIHR Training Program in Neurodegenerative Lipidomics (CTPNL) (TGF 96121) to SALB and JTA, and NSERC (5377) to SALB. CC is a recipient of the NSERC Canada Graduate Scholarship and a CTPNL and Institute of Aging Graduate Student Scholarship. CM is a recipient of the NSERC Undergraduate Student Research Award.

\section{CONFLICT OF INTEREST}

The authors have declared that there is no conflict of interest.

\section{REFERENCES}

1. Pfrunder A, Gutmann H, Beglinger C, Drewe J. Gene expression of CYP3A4, ABC-transporters (MDR1 and MRP1-MRP5) and hPXR in three different human colon carcinoma cell lines. J Pharm Pharmacol. 2003;55(1):59-66.

2. Watabe M, Isogai Y, Numazawa S, Yoshida T. Role of c-Myc in nitric oxide-mediated suppression of cytochrome P450 3A4. Life Sci. 2003;74(1):99-108.

3. Kuzmina E, Lejeune P, Dannenbaum D, Torrie JE. Cree Diabetes Information System 2009 Annual Report. Chisasibi: Cree Board of Health and Social Services of James Bay, 2010.

4. Hegele RA, Bartlett LC. Genetics, Environment and Type 2 Diabetes in the Oji-Cree Population of Northern Ontario. Canadian Journal of Diabetes. 2003;27(33):256-261. 
5. Young TK, Reading J, Elias B, O'Neil JD. Type 2 diabetes mellitus in Canada's first nations: status of an epidemic in progress. CMAJ. 2000;163(5):561566.

6. Leduc C, Coonishish J, Haddad P, Cuerrier A. Plants used by the Cree Nation of Eeyou Istchee (Quebec, Canada) for the treatment of diabetes: A novel approach in quantitative ethnobotany. J Ethnopharmacol. 2006;105(1-2):55-63.

7. Fraser MH, Cuerrier A, Haddad PS, Arnason JT, Owen PL, Johns T. Medicinal plants of Cree communities (Quebec, Canada): antioxidant activity of plants used to treat type 2 diabetes symptoms. Can J Physiol Pharmacol. 2007;85(11):1200-1214.

8. Ellison AM, Butler ED, Hicks EJ, Naczi RF, Calie PJ, Bell CD, et al. Phylogeny and biogeography of the carnivorous plant family Sarraceniaceae. PLoS One. 2012;7(6):e39291.

9. Gray SM, Akob DM, Green SJ, Kostka JE. The bacterial composition within the Sarracenia purpurea model system: local scale differences and the relationship with the other members of the food web. PLoS One. 2012;7(12):e50969.

10. Spoor DC, Martineau LC, Leduc C, BenhaddouAndaloussi A, Meddah B, Harris C, et al. Selected plant species from the Cree pharmacopoeia of northern Quebec possess anti-diabetic potential. Can J Physiol Pharmacol. 2006;84(8-9):847-858.

11. Harris CS, Asim M, Saleem A, Haddad PS, Arnason JT, Bennett SA. Characterizing the cytoprotective activity of Sarracenia purpurea L., a medicinal plant that inhibits glucotoxicity in $\mathrm{PC} 12$ cells. BMC Complement Altern Med. 2012;12:245.

12. Martineau LC, Adeyiwola-Spoor DC, Vallerand D, Afshar A, Arnason JT, Haddad PS. Enhancement of muscle cell glucose uptake by medicinal plant species of Canada's native populations is mediated by a common, metformin-like mechanism. J Ethnopharmacol. 2010;127(2):396-406.

13. Misra P. AMP activated protein kinase: a next generation target for total metabolic control. Expert Opin Ther Targets. 2008;12(1):91-100.

14. Viollet B, Lantier L, Devin-Leclerc J, Hebrard S, Amouyal C, Mounier R, et al. Targeting the AMPK pathway for the treatment of Type 2 diabetes. Front Biosci. 2009;14:3380-3400.

15. Shackelford DB, Shaw RJ. The LKB1-AMPK pathway: metabolism and growth control in tumour suppression. Nat Rev Cancer. 2009;9(8):563-575.

16. Rautou PE, Mansouri A, Lebrec D, Durand F, Valla $\mathrm{D}$, Moreau R. Autophagy in liver diseases. J Hepatol. 2010;53(6):1123-1134.

17. Zoncu R, Efeyan A, Sabatini DM. mTOR: from growth signal integration to cancer, diabetes and ageing. Nat Rev Mol Cell Biol. 2011;12(1):21-35.

18. Muhammad A, Guerrero-Analco JA, Martineau LC, Musallam L, Madiraju $\mathrm{P}$, Nachar A, et al.
Antidiabetic compounds from Sarracenia purpurea used traditionally by the Eeyou Istchee Cree First Nation. J Nat Prod. 2012;75(7):1284-1288.

19. Wang W, Xu J, Li L, Wang P, Ji X, Ai H, et al. Neuroprotective effect of morroniside on focal cerebral ischemia in rats. Brain Res Bull. 2010;83(5):196-201.

20. Yokozawa T, Kang KS, Park CH, Noh JS, Yamabe $\mathrm{N}$, Shibahara N, et al. Bioactive constituents of Corni Fructus: The therapeutic use of morroniside, loganin, and 7-O-galloyl-D-sedoheptulose as renoprotective agents in type 2 diabetes. Drug Discov Ther. 2010;4(4):223-234.

21. Park CH, Noh JS, Kim JH, Tanaka T, Zhao Q, Matsumoto K, et al. Evaluation of morroniside, iridoid glycoside from Corni Fructus, on diabetesinduced alterations such as oxidative stress, inflammation, and apoptosis in the liver of type 2 diabetic $\mathrm{db} / \mathrm{db}$ mice. Biol Pharm Bull. 2011;34(10):1559-1565.

22. Bailey DG, Dresser GK. Natural products and adverse drug interactions. CMAJ. 2004;170(10):1531-1532.

23. Foster BC, Foster MS, Vandenhoek S, Krantis A, Budzinski JW, Arnason JT, et al. An in vitro evaluation of human cytochrome P450 3A4 and Pglycoprotein inhibition by garlic. J Pharm Pharm Sci. 2001;4(2):176-184.

24. Pal D, Mitra AK. MDR- and CYP3A4-mediated drug-herbal interactions. Life Sci. 2006;78(18):2131-2145.

25. Ernst E, Gerada C, Hood S, Nutt D. A depressed man requesting St John's wort. Practitioner. 1999;243(1604):779-782.

26. Moore LB, Goodwin B, Jones SA, Wisely GB, Serabjit-Singh CJ, Willson TM, et al. St. John's wort induces hepatic drug metabolism through activation of the pregnane X receptor. Proc Natl Acad Sci U S A. 2000;97(13):7500-7502.

27. Obach RS. Inhibition of human cytochrome P450 enzymes by constituents of St. John's Wort, an herbal preparation used in the treatment of depression. J Pharmacol Exp Ther. 2000;294(1):8895.

28. Tam TW, Liu R, Arnason JT, Krantis A, Staines WA, Haddad PS, et al. Actions of ethnobotanically selected Cree anti-diabetic plants on human cytochrome P450 isoforms and flavin-containing monooxygenase $3 . \mathrm{J}$ Ethnopharmacol. 2009;126(1):119-126.

29. Tam TW, Liu R, Arnason JT, Krantis A, Staines WA, Haddad PS, et al. Cree antidiabetic plant extracts display mechanism-based inactivation of CYP3A4. Can J Physiol Pharmacol. 2011;89(1):1323. 
30. Muhammad A, Haddad PS, Durst T, Arnason JT. Phytochemical constituents of Sarracenia purpurea L. (pitcher plant). Phytochemistry. 2013;94:238-242.

31. Tusher VG, Tibshirani R, Chu G. Significance analysis of microarrays applied to the ionizing radiation response. Proc Natl Acad Sci U S A. 2001;98(9):5116-21.

32. Harbilas D, Martineau LC, Harris CS, AdeyiwolaSpoor DC, Saleem A, Lambert J, et al. Evaluation of the antidiabetic potential of selected medicinal plant extracts from the Canadian boreal forest used to treat symptoms of diabetes: part II. Can J Physiol Pharmacol. 2009;87(6):479-492.

33. Harbilas D, Brault A, Vallerand D, Martineau LC, Saleem A, Arnason JT, et al. Populus balsamifera L. (Salicaceae) mitigates the development of obesity and improves insulin sensitivity in a diet-induced obese mouse model. J Ethnopharmacol. 2012;141(3):1012-1020.

34. Harbilas D, Vallerand D, Brault A, Saleem A, Arnason JT, Musallam L, et al. Larix laricina, an Antidiabetic Alternative Treatment from the Cree of Northern Quebec Pharmacopoeia, Decreases Glycemia and Improves Insulin Sensitivity In Vivo. Evid Based Complement Alternat Med. 2012;2012:296432.

35. Harbilas D, Vallerand D, Brault A, Saleem A, Arnason JT, Musallam L, et al. Populus balsamifera Extract and Its Active Component Salicortin Reduce Obesity and Attenuate Insulin Resistance in a DietInduced Obese Mouse Model. Evid Based Complement Alternat Med. 2013;2013:172537.

36. International Transporter C, Giacomini KM, Huang SM, Tweedie DJ, Benet LZ, Brouwer KL, et al. Membrane transporters in drug development. Nat Rev Drug Discov. 2010;9(3):215-236.

37. El-Readi MZ, Eid S, Ashour ML, Tahrani A, Wink M. Modulation of multidrug resistance in cancer cells by chelidonine and Chelidonium majus alkaloids. Phytomedicine. 2013;20(3-4):282-294.

38. Raucy JL. Regulation of CYP3A4 expression in human hepatocytes by pharmaceuticals and natural products. Drug Metab Dispos. 2003;31(5):533-539.

39. Budzinski JW, Trudeau VL, Drouin CE, Panahi M, Arnason JT, Foster BC. Modulation of human cytochrome P450 3A4 (CYP3A4) and Pglycoprotein (P-gp) in Caco-2 cell monolayers by selected commercial-source milk thistle and goldenseal products. Can J Physiol Pharmacol. 2007;85(9):966-978.

40. Harborne JB. Arsenal for survival: secondary plant products. Taxon. 2000;49(3):435-449.

41. Guo Y, Chen Y, Tan ZR, Klaassen CD, Zhou HH. Repeated administration of berberine inhibits cytochromes P450 in humans. Eur J Clin Pharmacol. 2012;68(2):213-217.
42. Kaneko K, Suzuki K, Iwadate-Iwata E, Kato I, Uchida K, Onoue M. Evaluation of food-drug interaction of guava leaf tea. Phytother Res. 2013;27(2):299-305.

43. Krizkova J, Burdova K, Stiborova M, Kren V, Hodek P. The effects of selected flavonoids on cytochromes $\mathrm{P} 450$ in rat liver and small intestine. Interdiscip Toxicol. 2009;2(3):201-204.

44. Sergent T, Dupont I, Van der Heiden E, Scippo ML, Pussemier L, Larondelle Y, et al. CYP1A1 and CYP3A4 modulation by dietary flavonoids in human intestinal Caco-2 cells. Toxicol Lett. 2009;191(23):216-222.

45. Guo Y, Pope C, Cheng X, Zhou H, Klaassen CD. Dose-response of berberine on hepatic cytochromes P450 mRNA expression and activities in mice. $\mathrm{J}$ Ethnopharmacol. 2011;138(1):111-118.

46. Vrba J, Kren V, Vacek J, Papouskova B, Ulrichova J. Quercetin, quercetin glycosides and taxifolin differ in their ability to induce AhR activation and CYP1A1 expression in HepG2 cells. Phytother Res. 2012;26(11):1746-1752.

47. Jensen HR, Scott IM, Sims S, Trudeau VL, Arnason JT. Gene expression profiles of Drosophila melanogaster exposed to an insecticidal extract of Piper nigrum. J Agric Food Chem. 2006;54(4):12891295.

48. de Waard WJ, Aarts JM, Peijnenburg AA, Baykus H, Talsma E, Punt A, et al. Gene expression profiling in Caco-2 human colon cells exposed to TCDD, benzo[a]pyrene, and natural Ah receptor agonists from cruciferous vegetables and citrus fruits. Toxicol In Vitro. 2008;22(2):396-410.

49. Bermudez-Soto MJ, Larrosa M, Garcia-Cantalejo J, Espin JC, Tomas-Barberan FA, Garcia-Conesa MT. Transcriptional changes in human Caco-2 colon cancer cells following exposure to a recurrent nontoxic dose of polyphenol-rich chokeberry juice. Genes Nutr. 2007;2(1):111-113.

50. Gerhauser C, You M, Liu J, Moriarty RM, Hawthorne M, Mehta RG, et al. Cancer chemopreventive potential of sulforamate, a novel analogue of sulforaphane that induces phase 2 drugmetabolizing enzymes. Cancer Res. 1997;57(2):272278.

51. Butterweck V. Mechanism of action of St John's wort in depression : what is known? CNS Drugs. 2003;17(8):539-562.

52. Gonzalez-Sarrias A, Espin JC, Tomas-Barberan FA, Garcia-Conesa MT. Gene expression, cell cycle arrest and MAPK signalling regulation in Caco-2 cells exposed to ellagic acid and its metabolites, urolithins. Mol Nutr Food Res. 2009;53(6):686-698.

53. Canales RD, Luo Y, Willey JC, Austermiller B, Barbacioru CC, Boysen C, et al. Evaluation of DNA microarray results with quantitative gene expression platforms. Nat Biotechnol. 2006;24(9):1115-1122. 
54. Xu M, Li L, Liu Z, Jiao Z, Xu P, Kong X, et al. ABCB2 (TAP1) as the downstream target of $\mathrm{SHH}$ signaling enhances pancreatic ductal adenocarcinoma drug resistance. Cancer Lett. 2013;333(2):152-158.

55. Bezy O, Tran TT, Pihlajamaki J, Suzuki R, Emanuelli B, Winnay J, et al. PKCdelta regulates hepatic insulin sensitivity and hepatosteatosis in mice and humans. J Clin Invest. 2011;121(6):25042517.

56. Wolf A, Bauer B, Hartz AM. ABC Transporters and the Alzheimer's Disease Enigma. Front Psychiatry. 2012;3:54.

57. Lopes AM, Burgoyne PS, Ojarikre A, Bauer J, Sargent CA, Amorim A, et al. Transcriptional changes in response to $\mathrm{X}$ chromosome dosage in the mouse: implications for $\mathrm{X}$ inactivation and the molecular basis of Turner Syndrome. BMC Genomics. 2010;11:82.

58. Shippy R, Sendera TJ, Lockner R, Palaniappan C, Kaysser-Kranich T, Watts G, et al. Performance evaluation of commercial short-oligonucleotide microarrays and the impact of noise in making cross-platform correlations. BMC Genomics. 2004;5:61.

59. Morey JS, Ryan JC, Van Dolah FM. Microarray validation: factors influencing correlation between oligonucleotide microarrays and real-time PCR. Biol Proced Online. 2006;8:175-193.

60. Etienne W, Meyer MH, Peppers J, Meyer RA, Jr. Comparison of mRNA gene expression by RT-PCR and DNA microarray. Biotechniques. 2004;36(4):618-20, 22, 24-26. 